\title{
In Quest of “Answers” in the Colonial Sands: A Comparative Study of Waliullah and Camus’ “Absurd” Protagonists
}

\author{
Sanyat Sattar \\ Jahangirnagar University, Dhaka, Bangladesh
}

\author{
Abu Saleh Md. Rafi \\ Daffodil International University, Dhaka, Bangladesh
}

\begin{abstract}
Syed Waliullah (1922-1971) and Albert Camus (1913-1960) are two distinct writers from two different continents. These writers have interesting commonness, especially in two of their novels—Chander Amabasya (Night of No Moon), by Walilullah and The Outsider by Camus. The protagonists in both of these novels, Arif Ali and Meursault respectively, suffer from existentialist crisis, mainly fueled by the impacts of the tarnished history of colonialism and the aftermaths. Even though the stories of the these protagonists take place almost half way round the world in entirely different settings, the impacts and facades of the crisis are strikingly similar. This paper is a comparative study of soul-searching Arif Ali and Meursault.
\end{abstract}

Keywords: Existentialism, colonialism, postcolonialism, absurdity, meaninglessness, death

\section{Introduction}

When on a moonlit night in a mundane Bengali village, Arif Ali, a poor young school teacher discovers a half naked body of a strangled woman in the bamboo groove, a series of questions begins to plague him: Who killed that woman — why was she killed — had the life of the poor woman of no value — and so forth. The entire novel runs on these questions where Arif Ali suffers from a terrible internal war of choices and that puts him under the clutches of danger. In a Kafkaesque manner, Syed Waliullah reveals the fear, uncertainty, and mental tension of the protagonist Arif Ali in his novel Chander Amabasya (1964) as Arif Ali proceeds along the inescapable path to the moral responsibility.

The novel is written in the context of post 1947 East Pakistan (now Bangladesh). After the partition of the Subcontinent, this territory falls into the clutches of neo-colonization. The middle class becomes the worst victim in this process as they are doubly colonized by the high-educated-class of Bengali society powered by the Pakistani hegemony. Being manipulated by the name of "religious unity", the middle class realizes that they have actually been suppressed politically, economically, and culturally. And when their existential crisis swells, they feel the necessity of having a separate national identity. This awareness successfully results into the Bengali language movement of 1952. At that time a good number of writers, journalists, teachers start emerging from this middle class as a reactionary protest, but in the end of the decade they again are maneuvered as the "paid servant" in that hegemonic interpellation. In Chander Amabasya Arif Ali feels the affinity with the romantic ideas of the

Sanyat Sattar, Ph.D., associate professor \& Chair, Department of English, Jahangirnagar University. Abu Saleh Md. Rafi, M.A., lecturer, Department of English, Daffodil International University. 
middle class. Yet when the stark reality intervenes, the romantic ideas shatter. Placing Arif Ali as a tour guide in the changing socio-political statuesque of the Subcontinent, this paper aims to explore his existential crisis going beyond the national boundaries. In this connection, this paper collaborates Albert Camus' The Outsider (1942), to find how Arif Ali represents the recurring feature of existential crisis is equally reflected in Meursault, the protagonist of Camus' The Outsider offering historical and socio-political commentary of people of Bengal and Algerian societies respectively where the ambivalent relationship of colonizers and colonies is obvious.

\section{Arif Ali in The Crisis of Absurdity}

The entirely bleak and dark setting of the novel Chander Amabasya represents the afflicted society of 1940s when one day Karim Majhi, a poor boatman, had to run away owing to financial dearth, his deserted wife being killed in the bamboo groove for unknown reason and the protagonist, Arif Ali, had to face the death warrant even for not being responsible of the murder. In the background of the partition of India and Pakistan Arif Ali's life was also crucially parted away from any normal aspirations of life. He was forced to drop out his school, leave his mother alone in the village becoming an in-house lodging teacher at the households of Dada Shaheb, the powerful religious authority of the village. Though he realizes that Karim Majhi’s wife was killed by Qadir, the son of Dada Shaheb, he does not dare to render the murderer, not only because of his financial dependency on the family, but also for Dada Shaheb's manipulative religious dogma that announces Qadir as a Sufi. Qadir is a mute, aimless character, who apparently looks drowsy at his every single appearances. Yet he gains the recognition of being a "rebel” by the superstitious villagers, although nobody knows what he is rebelling against. Dada Shaheb, with his eyes closed declares quietly, "How would ordinary people understand the rebellion of a dervish?” (Walliullah, 2006, p. 60).

As a matter of fact, this was the actual picture of postcolonial Bangladesh during 1940s, when Dada Shaheb-like hegemonic powers were corrupting religion to be benefitted by enforcing false beliefs among the common people. In such socio-political setting, a renaissance man like Arif Ali is confused with everything. And the naked dead body seems to be triggering the inner questions more vividly. Is religion truly the space where sanity lies? Or is it just another weapon of exercising corruption? What do the high-sounding ideas of love, patriotism, sacrifice mean? Or are these just as meaningless as religion appears? What does education mean if the middle class is to "obey" their masters? All such thoughts drift in the mind of Arif Ali. Sometimes a vague sympathy rises in his heart for Qadir, imagining that Qadir might have had a love affair with that dead woman. Arif's idealistic philosophy keeps him acknowledging stark reality and he even thinks of forgiving the murderer he knows. On the top of that, the villain of the novel, Qadir, attempts to convince him by telling that it was a mere accident and he also threatens Arif Ali not to disclose what he saw in the bamboo groove unless he wants to die himself. But Arif Ali's conscience keeps continuously knocking him. Finally he reveals everything to the police, knowing that something sinister will happen to him soon. Arif's psychology is the picture-perfect representation of contemporary ideology of the middle class common people in the society who are exiled in fear, helplessness, inferiority complex, but at the same time remain responsible, self righteous and audacious to tell the truth. The absurdity lies in the fact that everything seems bleak, meaningless and confusing as there is nothing to do, but to accept the reality. Hence, this young teacher accepts this vague conclusion that no matter who is punished, it hardly matters to him anymore- 
What difference would it make as to who got punished as the meaning of the punishment would never reach the dead young woman any more. That was not why there should be a punishment. If the young teacher mistakenly brought the punishment on himself, if he himself were punished for the death of the young woman, then it would certainly reach its goal. (Walliullah, 2006, p. 150)

\section{Arif Ali Versus Albert Camus}

Interestingly, Albert Camus' personal life has striking similarities with the fictional character of Arif Ali. Due to his family's extreme poverty, Camus also had to work a series of odd jobs to support his education at the University of Algiers. However, he had to drop out of the school because of the severe attack of tuberculosis. His writing was greatly influenced by the illness and poverty he faced during his youth. But what affected his inner psyche the most was the horrors of Nazi regime and the evil consequences of the World War II that shattered the pre-war values of love, romanticism, optimism, prosperity, and hope. Camus and many other writers of that time, propounded the philosophy of absurdity of life, where life is meaningless and ends in meaninglessness—something that Arif Ali equally projects.

\section{Meursault, The Outsider}

Camus published his first novel The Outsider in 1942, in which the protagonist Meursault brilliantly emerges as the spokesman of Camus' absurdist worldview. He is an emotionally detached, morally bankrupt and spiritually sterile young man who is unable to reconcile with the past belief and also unwilling to accept those of the mainstream society. The romantic idea of war and patriotism, the shattered philosophy of life and religion, the lust and financial strings with the idea of love—all these have literally turned Meursault into the "outsider", for which he creates his own set of rules, and lives them unsympathetically. From his offhand sexual intercourse with Marie on the day after his mother's funeral, to his friendship with a violent pimp, to his needless murder of an Arab man whom he does not even know, projects himself as an absurdist. The trial of Mersault, however, is even more absurd. During the pre-trial hearings, the magistrate harasses Mersault about his religious belief while Mersault indicates that he is an atheist. The magistrate overreacts waving a silver crucifix in his face and calls him the "antichrist". During the trial, the audience appears to be more interested in the fact that Mersault did not grieve at his mother's funeral and made love to Marie on the day after the funeral than the fact that he has killed a man.

Here, the colonial history of Algeria needs to be pointed, as it reflects the mindset of the audience at the trail scene. Algeria was a colony of France and by 1940's, Algiers, the city in which The Outsider is set, was a French territory (it is worth mentioning here that the time setting of Waliullah's Chander Amabasya is also the 40s). In that colonial world, the French were considered superior to the Arabs and Arabs were considered as camel breading nomads, more suitable as slaves than anything else (Horowitz, 2006, p. 55). Thus in The Outsider the unknown Arab, remains "unknown” without any story and becomes the peculiarly unpleasant example of both racist and sexual exploitation. Horowitz emphasizes:

Whereas the majority of readers will see the failure to refer to the Arab's murder in the novel's second half as the result of Meursault's "solar" conditioning, which thus absolves him of premeditated intent to kill, other readers will come to see in such silence Camus's own [...] a silence that is thereby a sort of hegemony-in-narrative. The sleight of hand accorded the murder of the Arab throughout the second half is seen as Camus' own dismissal of the murder and preceding violence. (Horowitz, 2006, p. 55) 
From a postcolonial perspective, Camus' name generates a systematic nullification of Arab characters as evident in The Outsider. Meursault may "officially" be on trial for killing a man, but he is in fact on trial for his character, and it is for this character that he is convicted. Being a non-Arab, a representative of colonizer's community, Meursault's killing a colonized Arab was a minor offense, but not obeying the colonial customs as being part of the group of colonizers and not acting as a true Christian, was apparently more offensive and punishable crime. When Meursault himself says he has been convinced of his own guilt, he is probably not talking about murder at all. But it is an absurd sentence for a man who truly does not view himself as a criminal: "I was sure of myself, sure about everything, Sure of my present life and of the death that was coming [...] I'd been right, I was still right, I was always right” (Camus, 2000, p. 130).

\section{The Affinities of Absurdity}

From the comparative study attempted on Syed Waliullah's Chander Amabasya in conjunction with Albert Camus' The Outsider, this paper finds that both of the protagonists are in search for the answers of all the "meanings" of the signs and symbols of the clueless life. Life is seemingly a riddle and none of these characters are able to find the proper answer to anything.

The incongruous colonial history of the Subcontinent or in the African continent added with all numerous other concomitant of war fuels the absurdity in the fundamental reasoning of living in the mindset of Arif Ali and Meusault, who feel lost and aimless. By absurdity they try to escape from their traditional romantic ideas of living. Although from postcolonial perspective, Meursault stands as the colonizer, when Arif shares the experiences of being the colonized, their internalized emotional suffering is somewhat similar. In their individual social discrepancies, Arif Ali and Mersault begin the journey towards awareness, but inevitably encounter existentialist crisis, which stimulate them to instigate introspective thoughts. Meursault experiences existentialism throughout the novel, because he is detached from almost everybody. This detachment causes him to go through traumatic experiences, leading up to the end of the novel, where he comes to realize what kind of a life he has been living. Meursault can be considered as a strange character, who is looking for the meaning in life, yet at the same time abandoning it, and embracing apathy.

Unlike Meursault, Arif Ali needlessly involves himself with the odd turn of events in his life. When Qadir wanted his help to peter out the dead body, Arif could have rejected it. But he feels no reaction in his mind; rather he thinks some indomitable force pushing him towards the concluding scene of life. Even he cannot not understand what Qadir expects him to do: "It was not possible for him to distinguish truth from untruth, the common from uncommon, right from wrong any more’ which creates a complete absurd situation” (Walliullah, 2006, p. 90). Incorporating Qadir to evacuate the dead body and then complaining to the police against Qadir makes the circumstances even more absurd that intensifies Arif Ali's existential crisis. In the end of both Chander Amabasya and The Outsider neither Mersault nor Arif Ali's life gets a rational meaning or order. They have troubles dealing with their individual history against the national, although they continuously struggle to rationalize their nihilistic ideologies. This struggle to find meaning where none exists is what the existentialists call, "the absurd". So strong is their desire to acquire the meaning of life that they dismiss out of hand the idea that there is nothing to be found. When they realize the meaninglessness of their existence in that religiously occupied "absurd" society, they start living in the moment accepting death as the ultimate, yet absurd conclusion of life, 
through which they try to liberate themselves from the unattained pile of questions beneath their minds.

\section{Conclusion}

Growing up in the dawn of French colonization in Algeria or in the dusk of British empire in Bengal; both Meursault and Arif Ali indulge their personal history against the national history that interrogates the protagonists' existence in the realm of sufferings. Existentialism, the philosophy that mankind is entirely free and therefore responsible for their own actions, is prevalent in The Outsider and Chander Amabasya from each writers' cultural perspectives. There is also a concern with death and its inevitability in both novels. The writers involved their protagonists facing ethical dilemmas in the face of their realization that life is absurd and that it has no purpose in the world where there is no God, no caring, no love, and ultimately no meaning beyond death. This is where the cruel history wins and the colonized Arif Ali unites with colonizer Meursault, and none seems happy.

\section{References}

Aldridge, A. O. (1969). Comparative literature: Matter and method. Chicago: University of Illinois Press Urbana, IL.

Bassnett, S. (1993). Comparative literature: A critical introduction. Oxford: Blackwell.

Camus, A. (2000). The outsider. New York: Penguin.

Guillen, C. (1993). The challenges of comparative literature. Cambridge: Harvard University Press.

Horowitz, L. K. (2006). Of women and Arabs: Sexual and racial polarization in Camus. Retrieved from http://www.jstor.org/stable/3194734

Rafi, A. S. M. (2012). The comparative nature in comparative literature: A case-study of some major Bengali literary works in conjunction of other national literatures. Bangladesh Research Foundation Journal, 1, 89.

Waliullah, S. (2009). Chander Amabasya (8th ed.). Dhaka: Nouroze.

Walliullah, S. (2006). Night of No Moon. In A. Dil (Trans.). Dhaka: WritersInk. 